\title{
PEMBENTUKAN KOMUNITAS PENGELOLA SAMPAH TERPADU BERBASIS MASYARAKAT
}

\section{THE ESTABLISHMENT OF AN INTEGRATED COMMUNITY-BASED SOLID WASTE MANAGEMENT}

\author{
${ }^{1)}$ Eni Muryani, ${ }^{2)}$ Ika Wahyuning Widiarti, ${ }^{3)}$ Novia Devi Savitri \\ ${ }^{1,2,3)}$ Program Studi Teknik Lingkungan, Fakultas Teknologi Mineral \\ Universitas Pembangunan Veteran Yogyakarta \\ Jl. Padjajaran (SWK 104) Ringroad Utara, Condong Catur, Depok, Sleman, DIY \\ Email: eni.muryani@upnyk.ac.id
}

\begin{abstract}
ABSTRAK
Sebagian besar warga Dusun Gesikan Kelurahan Panggungharjo Sewon Bantul memperlakukan sampah dengancaradibakar atau dibuang ke sungai. Cara-cara ini akan menimbulkan permasalahan lingkungan. Pembentukan komunitas pengelola sampah terpadu berbasis masyarakat di Dusun Gesikan bertujuan untuk mengurangi permasalahan lingkungan karena sampah.Mitra yang terlibat dalam program ini adalah warga RT. 04 Dusun Gesikan Panggungharjo Sewon Bantul. Metode yang digunakan dalam kegiatan antara lain dengan penyuluhan/edukasi, pelatihan, dan pendampingan. Komunitas dibentuk melalui serangkaian kegiatan yaitu: 1) koordinasi dengan pengurus $R T$, pedukuhan, dan tokoh masyarakat; 2) sosialisasi dan edukasi tentang pengelolaan sampah dan bank sampah; 3) edukasi dan pemberian fasilitas pemilahan sampah; 4) pelatihan pembuatan kompos, pembuatan aneka kreasi daur ulang dari sampah plastik, dan pembuatan lilin dari minyak jelantah. Hasil yang dicapai berupa terbentuknya "Kompaster Gestari", yang merupakan kependekan dari Komunitas Pengelola Sampah Terpadu, Gesikan Resik Tertata dan Asri. Masyarakat yang bergabung dalam komunitas ini secara bertahap digiring untuk melakukan pengelolaan sampah secara sadar dan mandiri, menerapkan 6 M dan 2 TM yakni: mengurangi potensi sampah, memanfaatkan sampah, mendaur ulang sampah, memilah sampah, menabung sampah, meminimalkan sampah residu masuk ke TPA, tidak membuang sampah ke sungai, dan tidak membakar sampah. Produk utama Kompaster Gestari adalah Bank Sampah Gestari yang dibentuk pada tanggal 15 September 2019. Hasil produk daur ulang sampah seperti tatakan gelas, bunga dari kresek, dan lilin minyak jelantah telah dipamerkan di acara lomba desa Panggungharjo.Kompaster Gestari telah mendapat tawaran kerjasama dari Bumdes Panggungharjo, Bank Sampah "Gemah Ripah” Badegan Bantul, Butik Daur Ulang Project B Indonesia untuk pemasaran produk dan hasil tabung sampah.
\end{abstract}

Kata kunci: Komunitas; Pengelolaan Sampah Terpadu; Berbasis Masyarakat

\begin{abstract}
Most residents of the Gesikan Panggungharjo Sewon Bantul treat their waste by burning or dumping it into the river. These methods will cause environmental problems. The establishment of an integrated communitybased stable waste management community is to overcome ecological challenges caused by waste. The partners involved in this program are residents of RT. 04 Gesikan Panggungharjo Sewon Bantul. The methods used include counseling/education, training, and mentoring. The activities carried out are 1) coordination with RT administrators, hamlets, and community leaders; 2) socialization and education about waste management; 3) education about waste segregation; 4) training to make compost, various recycled creations from plastic waste, and making candles from used cooking oil. The results achieved in the form of the formation of "Kompaster Gestari," which is short for Komunitas Pengelola Sampah Terpadu, Gesikan Resik Tertata dan Asri. The community is encouraged to manage waste consciously and independently and apply $6 M$ and $2 T M$, namely reducing the potential for misuse, utilizing waste, recycling waste, sorting out garbage, saving garbage, minimizing extra garbage entering the landfill, not throwing garbage into the river, and not burning trash. The main product of Kompaster Gestari is Gestari Waste Bank, which was formed on September 15, 2019. The results of recycled waste products such as glass coasters, flowers from crackle, and used cooking oil candles have been exhibited at the Panggungharjo village competition event. Kompaster Gestari has received an offer of cooperation from Bumdes Panggungharjo, "Gemah Ripah" Waste Bank Badegan Bantul, Project B Indonesia Recycling Boutique for marketing products and the results of waste canisters.
\end{abstract}


Keywords: Community; Integrated Waste Management; Community-Based

Submitted : 5 September 2019 Revision : 8 November 2019 Accepted : 23 Februari 2020

\section{PENDAHULUAN}

Sampah masih menjadi permasalahan klasik di Indonesia yang belum dapat terpecahkan secara menyeluruh.Rendahnya pembiayaan penanganan sampah dari APBD dan kecilnya penerimaan retribusi sampah menyebabkan penanganan sampah belum maksimal. Selain itu, kurangnya kesadaran masyarakat untuk bertanggung jawab terhadap sampah yang dihasilkan menyebabkan penanganan sampah sering kali menurunkan kualitas lingkungan seperti membakar sampah, membuang sampah ke sungai atau menimbunnyadi tanah.

Kebiasaan tersebut kerap dijumpai di RT 04 Dusun Gesikan,Desa Panggungharjo, Kecamatan Sewon, Kabupaten Bantul. Membakar sampah termasuk sampah plastik dan membuang sampah ke sungai merupakan cara beberapa warga RT 04 Dusun Gesikan untuk menghilangkan sampah dari pandangan mata. Namun, beberapa warga lainnya menangani sampahnya dengan memanfaatkan jasa pengangkutan sampah. Sampah ini akan diangkut oleh mobil pick up dan dibawa ke Tempat Pengolahan Sampah Terpadu (TPST) Piyungan.

Padukuhan Gesikan, Desa Panggungharjo, Kecamatan Sewon, Kabupaten Bantul termasuk kawasan semi urban. Sebagai kawasan semi urban, di dusun ini masih memiliki area sawah dan kebun tetapi rumah penduduknya sudah padat seperti wilayah perkotaan. Padukuhan Gesikan berluas area 30 Ha dengan 1000 jiwa. Sebagian dari warganya bermata pencaharian sebagai petani, penggarap sawah, peternak, pekerja bangunan, pengrajin, sebagian kecil sebagai pegawai dan karyawan pabrik, serta berwirausaha (berjualan di pasar). Dengan beragamnya pekerjaan di wilayah ini menyebabkan beragamnya tingkat ekonomi warga yang selanjutnya dapat menjadi salah satu faktor beragamnya tingkat pengetahuan dan perilaku warga Gesikan dalam mengelola sampahnya.
Dinas Lingkungan Hidup Kabupaten Bantul melaporkan bahwa perkiraan timbulan sampah di Kabupaten Bantul pada Tahun 2016 sebesar 2.299,29 m3/hari. Sedangkan data pada Tahun 2017 menunjukkan bahwapotensi sampah yang berasal dari Kabupaten Bantul sebesar 20.408 ton/bulan, tetapi tingkat pelayanan penanganan sampah di Kabupaten Bantul hanya sebesar 7,49\%. Angka ini sangat kecil jika dibandingkan dengan Kabupaten Sleman dan Kota Yogyakarta yang berturutturut mencapai 30,71 \% dan $85 \%$ (Putra, 2018).Dalam Perpres No. 19 Tahun 2017 tentang Kebijakan dan Strategi Nasional Pengelolaan Sampah Rumah Tangga dan Sampah Sejenis Rumah Tangga, pemerintah menargetkan $70 \%$ sampah di berbagai wilayah Indonesia dapat tertangani pada Tahun 2025.

Salah satu upaya meningkatkan persentase penanganan sampah yang dilakukan oleh Kabupaten Bantul adalah dengan mengembangkan pengelolaan sampah berbasis 3R dan memperbanyak kelompok pengelola sampah berbasis masyarakat yang kemudian dapat tergabung dalam jejaring pengelola sampah mandiri. Jumlah pengelola sampah mandiri (PSM) di Kabupaten Bantul hingga Tahun 2018 sebanyak 62 kelompok PSM yang tersebar di 17 Kecamatan termasuk Kecamatan Sewon (DLH Kabupaten Bantul, 2018).

Terbentuknya pengelola sampah mandiri ini merupakan salah satu upaya memberdayakan dan melibatkan peran aktif masyarakat untuk mengelola sampahnya sendiri. Pemberdayaan adalah suatu proses yang menjadikan sekelompok masyarakat lemah menjadi lebih terberdayakan. Pemberdayaan yang sukses mampu membentuk sebuah kelompok menjadi mandiri secara berkelanjutan bukan hanya dibantu sesaat saja termasuk dalam pengelolaan sampah (Hadi, 2010).

Pemberdayaan masyarakat dengan membentuk komunitas pengelola sampah terpadu berbasis masyarakat dapat dilakukan di RT 04 Dusun Gesikan. Edukasi tentang dampak pembakaran sampah dan pembuangan sampah ke sungai tidak cukup untuk menyelesaikan 
permasalahan sampah.Perlu ada sistem yang dikembangkan agar masalah pengelolaan sampah di Dusun Gesikan dapat terselesaikan dari hulu ke hilir atau terpadu. Sistem yang akan dikembangkan adalah membentuk Komunitas Pengelola Sampah Terpadu Berbasis Masyarakat. Pembentukan komunitas pengelola sampah terpadu di wilayah RT 04 Panggungharjo Sewon Bantul ini didanai oleh hibah internal Pengabdian bagi Masyarakat UPN "Veteran" Yogyakarta.

Berbagai tahap dilalui agar tercapai terbentuknya komunitas ini, antara lain dengan edukasi pemilahan sampah, membentukBank Sampah, praktek membuat kompos skala rumah tangga, memberikan pelatihan dasar aneka kreasi daur ulang sampah, dan bekerjasama dengan pihak Desa Panggungharjo untuk pengelolaan sampah residu. Bank Sampah adalah suatu sistem pengelolaan sampah layak jual yang sistem operasionalnya seperti bank konvensional (Utami, 2013). Jika pada bank konvensional yang ditabung adalah uang, maka di bank ini yang ditabung adalah sampah. Oleh karenanya, agar sampah dapat ditabung maka warga diedukasi untuk melakukan pemilahan sampah.

Berdasarkan uraian tersebut, maka kegiatan pengabdian kepada masyarakat ini bertujuan untuk mengedukasi masyarakat tentang sampah dan pengelolaannya dan mengajak masyarakat untuk berpartisipasi aktif dalam pengelolaan sampah. Pembentukan komunitas pengelola sampah terpadu berbasis masyarakat di RT 04 Dusun Gesikan, Panggungharjo, Sewon, Bantul bertujuan untuk mengurangi permasalahan lingkungan, sebagai salah satu upaya mewujudkan cita-cita pemerintah dalam pengelolaan sampah, khususnya di Kabupaten Bantul. Dengan adanya kegiatan ini diharapkan pengelolaan sampah di Dusun Gesikan ke depannya akan dilaksanakan secara sadar dan mandiri serta tidak menimbulkan dampak negatif ke lingkungan.

\section{METODE}

$\begin{array}{lcr}\text { Metode yang } & \begin{array}{c}\text { digunakan } \\ \text { lain }\end{array} & \begin{array}{r}\text { didalam } \\ \text { dengan }\end{array} \\ \text { kegiatan antara } & \text { pelatihan, } & \text { dan } \\ \text { penyuluhan/edukasi, } & \text { RT. 04 Gesikan } \\ \text { pendampingan. Warga } & \text { RT. } \\ \text { Panggungharjo Sewon Bantul sebagai mitra } \\ \text { dalam kegiatan pengabdian masyarakat ini }\end{array}$

merupakan salah satu RT di Pedukuhan Gesikan dengan jumlah KK paling sedikit, bahkan se-Kapubaten Bantul. Terdapat $44 \mathrm{KK}$ di RT ini yang terbagi dalam 2 kelompok dasa wisma. Jumlah orang per KK rata-rata 3-5 orang. Jumlah mitra yang relatif sedikit dapat memudahkan proses edukasi, pelatihan, dan pendampingan pengelolaan sampah yang dilakukan. Dalam penanganan sampah, mitra masih menggunakan cara-cara yang dilakukan oleh masyarakat pada umumnya. Masingmasing rumah tangga mengelola sampahnya dengan caranya sendiri-sendiri, seperti: berlangganan pada jasa pemungut sampah dengan membayar retribusi Rp. 25.000,- tiap bulan; mengumpulkan sampah harian di kantong kresek, kemudian dibuang di TPS terdekat; membuang sampahnya di pekarangan, setelah kering di bakar; dan membuang sampahnya ke sungai dan kalen (saluran irigasi) yang melintasi pemukiman. Kegiatan membakar sampah, terutama sampah daun dari pekarangan menjadi pemandangan yang lazim dijumpai setiap hari. Ada pula yang.Beberapa warga juga ada yang telah melakukan pemilahan sampah untuk kemudian diberikan/dijual kepada pemulung ataupun pengepul. Karakter warga RT 04 Gesikan Panggungharjo secara umum bersifat terbuka dan mau menerima perubahan, sehingga pendekatan partisipatif dapat dilakukan untuk kegiatan pengabdian masyarakat ini. Pemberdayaan masyarakat untuk mengelola sampah melalui pembentukan komunitas pengelolaan sampah terpadu berbasis masyarakat di RT 04 Panggungharjo Sewon Bantul dilakukan melalui serangkaian tahap yaitu:

1. Koordinasi dengan pengurus RT, pedukuhan, dan beberapa tokoh masyarakat;

2. Sosialisasi tentang pengelolaan sampah;

3. Memberikan edukasi dan fasilitas pemilahan sampah;

4. Pendampingan dan edukasi di kampung wisata lingkungan, Sukunan Gamping Sleman;

5. Pendampingan dan edukasi di Bank Sampah Gemah Ripah, Badegan Bantul;

6. Pendekatan intensif pada kader-kader potensial untuk pengurus komunitas pengelola sampah; 
7. Monitoring dan pendampingan hasil edukasi pemilahan sampah;

8. Pelatiahan pembuatan kompos dari sampah organik dan memberikan fasilitas komposter;

9. Membentuk kepengurusan komunitas pengelola sampah yang diberi nama Kompaster Gestari (Komunitas Pengelola Sampah Terpadu Gesikan Resik Tertata dan Asri);

10. Membentuk pengurus dan mendirikan bank sampah yang diberi nama Bank Sampah Gestari;

11. Pelatihan aneka kreasi daur ulang sampah plastik;

12. Pelatihan pembuatan lilin dari minyak jelantah;

13. Mengajak masyarakat Pedukuhan Gesikan untuk bergabung ke Kompaster Gestari;

14. Mengenalkan Kompaster Gestari ke tingkat Kelurahan Panggungharjo;

15. Menjalin kerjasama dengan Bumdes Panggungharjo untuk pengelolaan sampah layak jual dan sampah residu;

16. Menjalin kerjasama dengan pengepul sampah layak jual dan pihak-pihak yang menerima produk hasil daur ulang.

Setelah berkoordinasi dengan tokohtokoh masyarakat, kegiatan pertama berupa sosialisasi mengenai program dan pengetahuan sampah.Sosialisasi dilakukan dengan metode ceramah dan diskusi. Materi yang diberikan berupa uraian program yang akan dilaksanakan selama 3 (tiga) bulan dalam rangka menuju pembentukan komunitas pengelola sampah, penyampaian pengetahuan tentang sampah, pemilahan sampah dan cara pengelolaan sampah yang berwawasan lingkungan. Setelah kegiatan sosialisasi, mitra dibagikan 3 kantong pemilah sampah yang digunakan mitra untuk belajar memilah sampah dengan pendampingan selama 2 bulan.

Kegiatan berikutnya adalah mitra didampingi untuk memperoleh edukasi tentang pengelolaan sampah mandiri di Desa Wisata Lingkungan Sukunan yang berada di Desa Banyuraden, Gamping, Kabupaten Sleman. Edukasi ini bertujuan untuk memotivasi dan menginspirasi mitra tentang pengelolaan sampah terpadu berbasis masyarakat di Desa Sukunan yang telah berjalan hingga 13 tahun.Selanjutnya, mitra didampingi untuk memperoleh edukasi tentang menabung sampah di Bank Sampah "Gemah Ripah”.Bank Sampah Gemah Ripah merupakan pioneer bank sampah di Indonesia yang berada di Dusun Badegan, Kabupaten Bantul. Di tempat ini mitra diberi pengetahuan tentang apa itu bank sampah, bagaimana cara mendirikan bank sampah dan mekanisme kerja bank sampah.

Pembentukkan pengurus komunitas pengelola sampah terpadu dan bank sampah "Gestari" didahului dengan pertemuan khusus dengan para warga yang sudah dibidik, memiliki potensi, dan tertarik untuk terlibat dalam operasional komunitas dan bank sampah.Pengurus kompaster terdiri dari ketua, sekretaris, dan bendahara. Pengurus bank sampah terdiri dari direktur, sekretaris, bendahara, dan teller. Setelah terbentuk pengurus, selanjutnya dilakukan praktek bank sampah yang diikuti oleh warga RT 04 dan sekitarnya yang telah memilah sampah. Kegiatan selanjutnya adalah memberikan berbagai pelatihan seperti pembuatan kompos dan pelatihan dasar pembuatan aneka produk daur ulang untuk mengenalkan Kompaster Gestari lebih luas ke masyarakat Gesikan dan Desa Panggungharjo. Selanjutnya komunitas ini menjalin kerjasama dengan berbagai pihak seperti Bumdes, pengepul sampah, dan para pemasar produk daur ulang.

\section{HASIL DAN PEMBAHASAN}

Kegiatan diawali dengan koordinasi dan sosialisasisecara langsung kepada tokohtokoh masyarakat seperti Dukuh, RT, dan orang-orang yang dituakan di lingkungan RT. 04 tentang gagasan untuk pembentukan komunitas pengelola sampah terpadu. Sosialisasi juga akan dilakukan melalui media sosial WhatsApp Group ibu-ibu maupun bapakbapak RT. 04. Sosialisasi juga dikemukakan pada acara rutin warga seperti arisan dan pengajian. Setelah sosialisasi, maka warga diundang untuk mengikuti acara penyuluhan tentang permasalahan sampah bagi lingkungan dan kewajiban masyarakat untuk menaati peraturan pemerintah tentang pengelolaan sampah. Materi yang disampaikan dalam sosialisasi awal program antara lain: isu terkini tentang permasalahan sampah, asal sampah, jenis-jenis sampah yang dihasilkan oleh rumah tangga, kemana larinya sampah, himbauan untuk bijak kelola sampah (dengan cara cegah, olah, dan manfaatkan sampah), cara memilah 
sampah, dan cara merawat sampah agar bernilai jual (Widiarti, 2019).

Penyuluhan tentang pengelolaan sampah dapat merubah persepsi dan pandangan masyarakat tentang peran mereka terhadap pengelolaan sampah.Dalam sosialisasi dan penyuluhan tentang sampah tersebut, warga diberikan edukasi dan fasilitas untuk memilah sampah. Warga diminta memilah sampah layak jual dalam 3 kategori utama yakni: plastik, kertas/dupleks, dan bungkus kemasan. Pendampingan dan monitoring pemilahan sampah kepada mitra dilakukan selama kurang lebih 2 bulan.

Menurut Sucipto (2012), pemilahan sampah minimal dilakukan dengan memilahnya menjadi dua jenis yaitu sampah basah (organik) dan sampah kering (anorganik). Lebih baik lagi jika dipilah menurut komponennya seperti sampah kertas, plastik, gelas, logam dan sampah basah yang mudah membusuk. Hal inilah yang mendasari kategori pemilahan sampah yang dilakukan oleh warga RT 04.

Kegiatan berikutnya berupa pendampingan kepada mitra untuk memperoleh edukasi tentang pengelolaan sampah secara terpadu di Desa Sukunan. Gambar 2 menyajikan foto kegiatan pendampingan dan edukasi di Desa Sukunan.

Desa Sukunan Gamping Sleman merupakan salah satu Desa Wisata Lingkungan di Yogyakarta. Desa Sukunan telah 13 tahun menerapkan pengelolaan sampah mandiri berbasis masyarakat.Edukasi yang diperoleh menjadikan mitra lebih terbuka wawasannya dan termotivasi untuk melakukan pengelolaan sampah secara terpadu dan mandiri melalui suatu wadah berupa komunitas pengelola sampah terpadu (Kompaster) di Dusun Gesikan Bank Sampah Gemah Ripah berada di Dusun Badegan, Bantul. Perintisan bank sampah gemah ripah dimulai dari lingkup 1 RT, dan kini berkembang di seluruh Indonesia.

Pengetahuan yang didapat oleh mitra dari hasil edukasi bank sampah adalah tentang apa itu bank sampah, bagaimana cara mendirikan bank sampah dan mekanisme kerja bank sampah.

Masalah sampah di berbagai kota di Indonesia dapat dipecahkan dengan baik apabila peran aktif masyarakat meningkat. Pada umumnya proses pengelolaan sampah dengan basis komunal dari beberapa tahapan proses, antara lain (Hoesein, 2010):

1. Mengupayakan agar sampah dikelola, dipilah dan diproses tahap awal mulai dari tempat timbulan sampah itu sendiri (dalam hal ini mayoritas adalah lingkungan rumah tangga).

2. Pada fase awal di tingkat rumah tangga setidaknya diupayakan untuk mengolah sampah organik menjadi kompos dan sampah anorganik dipilah serta dikumpul menurut jenisnya sehingga memungkinkan untuk di daur-ulang.

3. Tahapan selanjutnya adalah pengolahan sampah yang tidak memungkinkan untuk diolah di setiap lingkungan rumah tangga yang mempunyai TPS.

4. Tahapan akhir adalah pengangkutan sisa akhir sampah, sampah yang tidak dapat didaur ulang atau tidak dapat dimanfaatkan lagi di TPS sekitar 10-20\% sampah menuju TPA.

Pada tingkat operasional, sistem pengelolaan sampah terpadu merupakan kombinasi dari sistem pengelolaan sampah dengan cara daur ulang, pengkomposan, pembakaran (insinerator) dan sistem pembuangan akhir dengan cara sanitary landfill (Sucipto, 2012).

Hasil pengamatan menunjukkan bahwa setelah kegiatan pendampingan dan edukasi tentang pengelolaan sampah dan menabung sampah, warga RT.04 Gesikan sangat antusias dan sudah ada semangat untuk melakukan upaya pengelolaan sampah. RT 04 bercita-cita mewujudkan lingkungan Dusun Gesikan yang resik, tertata, dan asri (Gestari) dengan membentuk kader-kader dalam komunitas pengelola sampah terpadu berbasis masyarakat. Kader-kader ini dibidik dan dilakukan pendekatan intensif guna berpartisipasi aktif dalam kegiatan selanjutnya. Kader-kader inilah yang menjadi pengurus "Kompaster Gestari" (Komunitas Pengelola Sampah Terpadu Gesikan Resik Tertata, dan Asri) dan Bank Sampah "Gestari". Keterlibatan warga dalam kepengurusan komunitas dilakukan dengan suka rela dan tanpa paksaan. Pengurus komunitas merupakan penggerak utama dalam keberlanjutan program pengelolaan sampah di Dusun Gesikan. 
Guna menangani permasalahan sampah organik, warga Dusun Gesikan dikenalkan beberapa metode pengomposan. Dalam pelatihan ini, warga dikenalkan 4 metode pengomposan yaitu: metode takakura, metode lubang biopori, metode komposter, dan metode jugangan. Praktek pembuatan kompos dan pemberian sarana pengomposan dilakukan oleh Tim Pengabdian Masyarakat UPN Veteran Yogyakarta dari Prodi Teknik Lingkungan. Gambar 4 merupakan foto yang menunjukkan kegiatan koordinasi pengurus kompaster gestari dalam rangka persiapan pembentukan bank sampah dan pelatihan kompos.

Hasil utama yang dicapai dari kegiatan Pengabdian bagi masyarakat ini berupa terbentuknya "Kompaster Gestari", yang merupakan kependekan dari Komunitas Pengelola Sampah Terpadu, Gesikan Resik Tertata dan Asri. Masyarakat Dusun Gesikan yang bergabung dalam komunitas ini secara bertahap digiring untuk melakukan pengelolaan sampah secara sadar dan mandiri, menerapkan $6 \mathrm{M}$ dan 2 TM yakni: mengurangi potensi sampah, memanfaatkan sampah, mendaur ulang sampah, memilah sampah, menabung sampah, meminimalkan sampah residu masuk ke TPA, tidak membuang sampah ke sungai, dan tidak membakar sampah.

Bank Sampah Gestari merupakan produk utama dari kegiatan Kompaster Gestari.Bank Sampah Gestari pertama kali dikenalkan pada masyarakat Dusun Gesikan pada tanggal 15 September 2019. Awal kegiatan bank sampah berhasil mendapatkan 34 nasabah dengan hasil penjualan sampah sekitar Rp. 250.000,-.

Praktik bank sampah Gestari dilaksanakan di Balai RT. 04, diikuti seluruh perwakilan KK yang ada di RT 04 Gesikan. Adapun langkahlangkah dalam praktik bank sampah yang dilakukan adalah sebagai berikut :

1. Warga mengisi formulir pendaftaran anggota baru bank sampah yang sudah dibagikan.

2. Warga mengisi administrasi berupa daftar hadir dan menyerahkan formulir pendaftaran kepada petugas administrasi.

3. Formulir yang telah diserahkan selanjutnya akan digunakan sebagai acuan pembuatan buku tabungan anggota bank sampah.
4. Warga menyerahkan sampah yang telah dibawa dan dipilah kepada petugas penimbang.

5. Sampah yang telah diserahkan kepada petugas kemudian ditimbang.

6. Sampah yang telah ditimbang kemudian didata jenis dan beratnya sampah oleh petugas.

7. Warga diberikan bukti surat penerimaan yang berisikan berat sampah hasil dari pemilahan masing-masing warga.

8. Hasil dari sampah warga yang telah terkumpul kemudian dipisahkan sesuai jenisnya dan selanjutnya dibawa kepada pengepul.

Hasil penjualan sampah kemudian dikalkulasi dan ditulis pada buku rekening. Buku rekening dibagikan kembali kepada pemilik. Dua puluh persen dari hasil penjualan sampah akan dipergunakan untuk biaya operasional dan masuk kas pengelola.

Sampah bungkus kemasan pada umumnya tidak laku dijual, oleh karena itu dilakukan pula pelatihan pembuatan kreasi daur ulang dari bungkus kemasan dan kresek bekas. Pelatihan ini melibatkan Project B Indonesia yang merupakan pioneer pengusaha produk daur ulang di Yogyakarta. Pihak Project B Indonesia langsung menawarkan kerjasama berupa pembelian produk kreasi daur ulang yang dihasilkan oleh warga secara tunai dibayar dimuka apabila sesuai dengan standar mutu tertentu yang ditetapkan.

Tim PbM UPN Veteran Yogyakarta juga menggandeng Bank Sampah Gemah Ripah dalam pelatihan pembuatan lilin dari minyak jelantah. Bank Sampah Gemah Ripahpun menawarkan kerjasama pemasaran produk hasil kreasi daur ulang warga dengan sistem penitipan, jika produk laku baru akan dibayarkan. Bank Sampah Gemah Ripahpun bersedia menerima sampah-sampah yang tidak laku jual di pengepul seperti plastik kresek.

$$
\text { Langkah selanjutnya adalah }
$$
mengenalkan Kompaster Gestari secara luas ke Pedukuhan Gesikan dan Tingkat Desa Panggungharjo agar dapat menjalin kerjasama dengan Bumdes Panggungharjo untuk menangani sampah residu. Dalam acara lomba desa tanggal 28 September 2019, RT 04 Gesikan telah mengenalkan Kompaster dan Bank Sampah Gestari ke tingkat Desa Panggungharjo. Dalam acara ini juga 
didemontrasikan cara pembuatan lilin dari minyak jelantah dan produk-produk hasil daur ulang seperti tatakan gelas dan bunga dari kresek yang cara pembuatannya telah dikuasai oleh warga RT.04. Pengelolaan sampah terpadu dapat didefinisikan sebagai upaya penanganan sampah yang dimulai dari sumbernya (waste reduction), kemudian diikuti dengan pemanfaatan kembali (recycling), proses stabilisasi artinya melakukan efisiensi dan efektivitas pengelolaan sampah, dan memastikan pengolahan sampah di TPA dilakukan dengan benar (Sucipto, 2012). Sistem pengelolaan sampah terpadu dinilai tepat dan dapat diterapkan untuk memecahkan permasalahan sampah di kota (Saputra, 2013).

Dalam pemilahan sampah, tidak hanya diperlukan peran serta masyarakat, tetapi juga diperlukan pengelolaan sampah yang sudah memadai, baik berupa sarana-sarana fisik atau peralatan maupun sarana non fisik yang berupa penyuluhan, pengawasan, pemantauan dan peraturan yang berjalan dengan baik secara profesional, tidak hanya secara kuantitatif saja. Dari hasil penelitian BPPT, terbukti bahwa peran serta masyarakat dalam pemilahan sampah harus ditunjang dengan penyediaan sarana yang sudah terpilah juga, seperti misalnya tempat sampah terpilah, gerobak terpilah, jadwal pengangkutan yang berbeda dan konsisten atau kesinambungan sistem dari mulai proses kompos, daur ulang pembakaran dan pembuangan akhir. Dengan kata lain, masyarakat akan memberikan peran serta yang baik bila pihak pengelola kebersihan telah menyediakan sistem yang baik pula (Sucipto, 2012). Untuk mewujudkan hal ini kompaster Gestari harus bekerjasama dengan Kelurahan Panggungharjo yang saat ini sedang menggalakkan program Gade Sampah dan terus bergerak memperkenalkan program-program pengelolaan sampah yang bersahabat dengan lingkungan, mengenalkan konsep $6 \mathrm{M}$ dan 2 TM, serta mengajak orang-orang sekitar untuk melaksanakannya secara sadar dan mandiri.

Sampah rumah tangga dari masyarakat pedesaan pada umumnya tidak berakhir di TPA, namun berakhir di lingkungan sungai sekitarnya, saluran irigasi yang menuju sawah, kebun pribadi, dan insenerator tradisional alias dibakar secara konvensional.Jarang sekali masyarakat desa yang menggunakan jasa pemungut sampah untuk dibawa ke TPA karena harus membayar retribusi.Berdasarkan berbagi literatur yang ada, maka kegiatan pembentukan komunitas pengelola sampah terpadu berbasis masyarakat di RT 04 Panggungharjo Sewon Bantul disesuaikan dengan pola kehidupan masyarakat pedesaan dalam mengelola sampah. Masyarakat diberikan sosialisasi, stimulus, berbagai edukasi, pelatihan, pendampingan, dan dukungan dana pada awal pembentukan komunitas pengelola sampah terpadu. Selanjutnya komunitas ini diharapkan dapat bergerak secara sadar dan mandiri serta berkelanjutan.

Pendekatan komunitas pengelola sampah terpadu yang dibentuk ini merupakan manifestasi dari sistem 3R yang saat ini sudah merupakan konsensus internasional yaitu: Reduce, Reuse, Recycle atau 3M (Mengurangi, Menggunakan kembali, Mendaur ulang). Terdapat beberapa modifikasi dalam program ini menjadi $6 \mathrm{M}$ dan $2 \mathrm{TM}$. Masyarakat yang bergabung dalam komunitas ini secara bertahap akan digiring untuk melakukan pengelolaan sampah secara sadar dan mandiri dengan menerapkan $6 \mathrm{M}$ dan $2 \mathrm{TM}$ yakni: Mengurangai potensi sampah, Memanfaatkan sampah, Mendaur ulang sampah, Memilah sampah, Menabung sampah, Meminimalkan sampah residu masuk ke TPA, Tidak Membuang sampah ke sungai, dan Tidak Membakar sampah. Setidaknya ada 16 tahap yang dilakukan dalam kegiatan pembentukan komunitas pengelola sampah terpadu berbasis masyarakat yang diberi nama "Kompaster Gestari". Kompaster singkatan dari Komunitas Pengelola Sampah Terpadu. Gestari diambil dari nama Dusun Gesikan yang harapannya akan menjadi Resik Tertata dan Asri karena adanya komunitas pengelola sampah. RT 04 sebagai inisator awal pembentukan komunitas ini. Harapannya, anggota komunitas akan berkembang ke seluruh pedukuhan Gesikan. Tidak menutup kemungkinan akan berkembang ke wilyah Desa Panggungharjo dan Kabupaten Bantul.

Pengelolaan sampah berbasis masyarakat merupakan pengelolaan sampah yang melibatkan seluruh lapisan masyarakat. Masyarakat dilibatkan pada pengelolaan sampah dengan tujuan agar mayarakat menyadari bahwa permasalahan sampah merupakan tanggung jawab seluruh lapisan masyarakat (Sucipto, 2012).Metode ceramah dan diskusi saja tidak cukup untuk membentuk suatu komunitas pengelola sampah berbasis 
masyarakat. Penyampaian ide dan gagasan melalui tokoh-tokoh masyarakat telah dilakukan jauh sebelumnya.

Program mengurangi atau minimalisasi sampah dapat dimulai sejak pengumpulan, pengangkutan dan sistem pembuangan sampah (Sucipto, 2012). Dengan demikian program pengelolaan sampah ini dapat dilakukan di setiap tahapan sistem pengelolaan sampah. Idealnya dengan pengurangan sampah ini sudah dapat dimulai sejak awal dari sumbernya, yaitu sejak pewadahan sebagai bagian dari subsistem terdepan. Hal ini berhubungan langsung dengan peran serta masyarakat sebagai penghasil sampah itu sendiri.Kegiatan ini melibatkan kita semua, karena kita semua adalah penghasil sampah atau sumber sampah tersebut (Sucipto, 2012).

\section{SIMPULAN}

Pengelolaan sampah terpadu ataupun mandiri berbasis masyarakat tidak dapat diwujudkan dengan hanya sekedar memberikan penyuluhan atau sosialisasi saja.Harus ada sekelompok orang/komunitas yang mau bergerak dan memberikan contoh terlebih dahulu kepada warga disekitarnya. Langkahlangkah pembentukan komunitas pengelola sampah terpadu berbasis masyarakat yang ditulis dalam publikasi ini kiranya dapat dijadikan referensi untuk terbentuknya komunitas serupa di tempat lain.

\section{DAFTAR PUSTAKA}

DLH Kabupaten Bantul.(2018). Informasi Kinerja Pengelolaan Lingkungan Hidup Derah Kabupaten Bantul.DLH : Bantul.

Hadi, A. P. (2010). Konsep Pemberdayaan, Partisipasi dan Kelembagaan dalam Pembangunan. Yayasan Agribisnis/Pusat Pengembangan Masyarakat Agrikarya (PPMA).http://suniscome.50webs.com $132 \% 20$ Konsep $\% 20$ Pemberdayaan $\% 2$
0Partisipasi\%20Kelembagaan.pdf diakses 27 September 2019.

Hoesein, A. H. (2010). Pengelolaan Sampah Terpadu Berbasis Masyarakat. Kompasiana $27 \quad$ November 2010.https://www.kompasiana.com/ha srulhoesein/550049f08133112819fa75 78/pengelolaan-sampah-terpaduberbasis-masyarakat.tanggal September 2019.

Peraturan Presiden Nomor 97 Tahun 2017 Tentang Kebijakan dan Strategi Nasional Pengelolaan Sampah Rumah Tangga dan Sampah Sejenis Rumah Tangga.

Putra, H. P., Damanhuri, E., \& Sembiring, E. (2018).Integration of formal and informal sector (waste bank) in waste management system in Yogyakarta, Indonesia.In MATEC Web of Conferences (Vol. 154, p. 02007)

Saputra, A. W. (2013). Pengolahan Sampah Terpadu. Kompasiana 11 April 2013.https://www.kompasiana.com/ari wibowosaputra/552f9c616ea834bf7a8 b45d7/pengolahan-sampah-terpadu. tanggal 27 September 2019.

Sucipto, C. D. (2012). Teknologi Pengolahan Daur Ulang Sampah. Gosyen Publishing. Yogyakarta.

Utami, Eka. (2013). Panduan Sistem Bank Sampah \& 10 Kisah Sukses. Unilever Indonesia. Jakarta.

Widiarti, I. W., dan Eni M. (2019). Pelatihan Pengelolaan Sampah Organik dan Anorganik Pada Warga Dusun Gesikan, Kelurahan Panggungharjo, Kabupaten Bantul.Prosiding Seminar Nasional Ke-5 Hasil Penelitian dan Pengabdian Masyarakat 